\title{
MEDIA ANALISIS OSILATOR HARMONIK PADA PEGAS BERBASIS GRAPHIC USER INTERFACE (GUI)
}

\author{
Nurullaeli $^{1}$, Irnin Agustina Dwi Astuti ${ }^{2}$ \\ Program Studi Informatika, FTIK, Universitas Indraprasta PGRI ${ }^{1}$ \\ Program Studi Pendidikan Fisika, FMIPA, Universitas Indraprasta PGRI ${ }^{2}$ \\ Email: leli.biofisika@gmail.com
}

Diterima: 28 Januari 2019. Disetujui: 10 Mei 2019.

\begin{abstract}
Abstrak
Tujuan dari penelitian ini adalah membuat Graphic User Interface (GUI) sebagai media analisis data eksperimen (perhitungan konstanta pegas) dan analisis konsep osilator harmonik pada pegas. Metode yang digunakan, yaitu regresi linear, Runge-Kuttaorde 4 (RK4), dan ode45 berbantukan bahasa pemrograman Matlab. Penggunaan GUI dalam perhitungan konstanta pegas maupun analisis konsep osilator harmonik pada pegas akan lebih akurat dan menghemat waktu. Dalaman alisis konsep osilator harmonik pada pegas, metode numerik ode 45 untuk rentang waktu yang lebar lebih mendekati nilai sebenarnya dibanding metode RK4.
\end{abstract}

Kata Kunci: osilator harmonik, pegas, graphic user interface.

\section{Abstract}

The purpose of this study is to create a Graphic User Interface (GUI) as a medium for data research analysis (spring constant calculation) and to analyze the harmonic oscillator concept on spring. The method used linear regression, 4th order Runge-Kutta (RK4), and ode45 assisted with Matlab programming language. The usage of GUI in spring constants calculation and analyzing the concept of a harmonic oscillator on a spring will be more accurate and time-saving. In the harmonic oscillator concept analysis on spring, the numerical method ode45 with a wide span of time closed to actual value if compared to RK4 method.

Keywords:harmonic oscillator, spring, graphic user interface.

\section{PENDAHULUAN}

Osilator harmonik merupakan salah satu fenomena fisis yang dipelajari pada mata kuliah fisika dasar. Fenomena tersebut banyak terjadi di sekitar kita, salah satunya pada pegas tergantung secara vertikal yang diberi beban. Pada tingkat perkuliahan, umumnya dalam pembelajaran materi osilator harmonik pada pegas, mahasiswa melakukan eksperimen di laboratorium. Eksperimen tersebut selain untuk memahami peristiwa osilasi juga untuk menghitung konstanta pegas. 
Nurullaeli., Agustina. -Media Analisis Osilator Harmonik...

\begin{abstract}
Pendidikan saat ini dapat diintegrasikan dengan berbagai teknologi termasuk komputer, namun yang perlu diperhatikan adalah kesesuaian antara konteks dan juga potensi dari jenis teknologi yang digunakan dalam kegiatan pembelajaran yang ada (Aththibby, Lubis, \& Ardiyanti). Pendidikan harus memanfaatkan kelimpahan teknologi untuk memberikan pendidikan kepada siswa di mana saja dan kapan saja (López Cruz \& Gutierrez Cortes, 2012). Adanya teknologi komputasi yang ada banyak menghadirkan kemampuan modeling dari proses dan fenomena fisika sehingga dapat dengan mudah diselesaikan dengan metode numerik dan menggunakan komputer (Leader, 2004).
\end{abstract}

Penelitian mengenai konstanta pegas pernah dilakukan oleh Santosa (2010), dengan mengembangkan perangkat pengukuran konstanta pegas berbasis komputer. Untuk mendeteksi simpangan pegas setiap saat digunakan satu perangkat alat yang meliputi magnet, kumparan dan interface pengumpul data Vernier LabPro. Dari osilasi harmonis yang teramati dapat diperoleh frekuensi osilasinya dan selanjutnya dapat ditentukan nilai konstanta pegas yang digunakan.

Penelitian lain mengenai pengukuran konstanta pegas dilakukan oleh Alkautsar dan Suprijadi (2012), dengan sistem object tracking untuk menentukan posisi pada perhitungan konstanta pegas dengan memanfaatkan pengolahan citra pada citra bergerak. Selisih konstanta pegas yang didapatkan melalui pengolahan citra dengan cara mekanik melalui metoda statik sebesar $\pm 2.51 \%$ sedangkan melalui metoda dinamik sebesar 4.05 $\%$. Perhitungan konstanta pegas dari penelitian Santoso maupun Alkautsar dan Suprijadi masih dilakukan secara manual, sehingga membutuhkan waktu yang lama.

Persamaan osilator harmonik pada pegas dinyatakan dalam bentuk persamaan diferensial biasa orde 2 . Persamaan diferensial biasa dapat diselesaikan dengan metode analitik dan numerik. Penyelesaian secara analitik memberikan nilai eksak, sedangkan secara numerik memberikan nilai taksiran. Akan 
Nurullaeli., Agustina. -Media Analisis Osilator Harmonik...

tetapi, beberapa persamaan diferensial tidak bisa diselesaikan secara analitik (Sihombing \& Dahlia, 2018).

Metode numerik disebut juga sebagai metode alternatif dari metode analitik, yang merupakan metode penyelesaian persoalan matematika dengan rumus-rumus aljabar yang sudah baku atau lazim (Costa et al., 2014). Runge-Kutta merupakan salah satu metode numerik yang dapat digunakan untuk menyelesaikan persamaan diferensial biasa. Tingkat ketelitian dari metode ini dipengaruhi oleh ordenya. Semakin besar ordenya maka semakin teliti hasil yang diperoleh (Fardinah, 2017). Contoh metode Runge-Kutta yang populer digunakan dalam penyelesaian persamaan diferensial biasa, yaitu RK4 dan RKF45.

Dalam penyelesaian persamaan diferensial biasa menggunakan RK4 dan RKF45 dapat dilakukan dengan bantuan bahasa pemograman Matlab. Metode RKF45 pada bahasa pemrograman tersebut telah disediakan dalam fungsi panggilan ode45. Menurut Chapra (2012) fungsi ode45 menggunakan algoritma yang dikembangkan oleh Dormand and
Prince (1980), yang sekaligus menggunakan formula RK4 dan RK5 untuk mencari solusi. Matlab merekomendasikan ode45 sebagai fungsi yang diterapkan terlebih dahulu untuk sebagian besar masalah.

Kemampuan setiap mahasiswa dalam menggunakan Matlab tidak sama, ada beberapa mahasiswa yang kurang mahir dalam menulis sintak program sehingga bahasa pemrograman yang diharapkan mempermudah dalam menyelesaikan persamaan deferensial pada ayunan matematis malah menjadi rumit (Nurullaeli \& Astuti, 2018). Hal ini juga berlaku untuk penyelesaian persamaan diferensial yang lain, termasuk pada pegas. Oleh karena itu, peneliti membuat Graphic User Interface (GUI) sebagai media analisis data eksperimen dan konsep osilator harmonik pada pegas.

Dengan penggunaan media simulasi Matlab ini, maka dosen tidak harus menjelaskan materi pelajaran secara berulang-ulang. Apabila selama ini sebagian potensi Dosen tercurahkan kepada penyajian materi belajar di depan kelas secara konvensional, maka hal tersebut dapat 
dikurangi, sehingga perhatian dosen dapat lebih diarahkan kepada pengembangan dan pendalaman (Apriandi, \& Setyansah, 2017).

Semua operasi matematika dalam Matlab terutama yang digunakan dalam penelitian ini adalah operasi matriks. Matlabdapat menunjukkan hasil perhitungandalam bentuk grafik dan dapat dirancangsesuai keinginan kita menggunakan GUI (Hutagalung, 2018).

Metode yang dipakai, yaitu regresi linear, RK4, dan ode45 berbantukan bahasa pemograman Matlab. Penelitian ini diharapkan dapat menambah deretan media pembelajaran, khususnya konsep osilator harmonik pada pegas.

\section{METODE}

Penelitian inidilaksanakan di Laboratorium Fisika Universitas Indraprasta PGRI. Peralatan yang digunakan dalam penelitian yaitu sebuah laptop dengan prosesor Intel Core i5-2450M, $2.5 \mathrm{GHz}$, HDD 640 GB, memori 4 GB. Software yang digunakan dalam penelitian ini adalah Matlab (Matrix Laboratory) R2013a dan MS. Office 2010. Data penelitian diperoleh dari hasil eksperimen pegas tergantung secara vertikal yang diberi beban di laboratorium. Data yang didapat, kemudian dianalisis secara numerik dengan bantuan bahasa pemrograman Matlab. Metode yang digunakan yaitu metode regresi linier. Selain analisis data eksperimen, penelitian ini juga menganalisis konsep osilator harmonik pada pegas secara umum. Metode yang digunakanyaitumetode RK4 dan ode45 dengan bantuan bahasa pemrograman Matlab.

Pada pegas teregang karena adanya gaya berlaku hukum Hooke dengan persamaan

$F=-k x$

tanda negatif pada persamaan di atas berarti bahwa gaya yang bekerja pada benda selalu berlawanan arah dengan arah simpangannya dan posisi setimbang adalah pada saat $x$ sama dengan 0 .

Hukum Newton kedua juga berlaku pada peristiwa tersebut sehingga didapatkan persamaan

$$
m a=-k x
$$

Pada persamaan osilator harmonik berlaku 
$a=-\omega^{2} x=-\left(\frac{2 \pi}{T}\right)^{2} x$

apabila persamaan

tersebut disubsitusikan ke persamaan diatasnya maka akan didapatkan

$T^{2}=\frac{4 \pi^{2} m}{k}$

dimana $\mathrm{T}^{2}=$ kuadrat periode osilasi, $\mathrm{m}=$ massa beban, dan $\mathrm{k}=$ konstanta pegas.

Perhitungan konstanta pegas dicari menggunakan metode regresi linear. Persamaan regresi linear yaitu sebagai berikut

$\bar{y}=a \bar{x}+b$

Sesuai dengan grafik hubungan antara kuadrat periodik (sebagai sumbu y) terhadap massa beban (sebagai sumbu $\mathrm{x}$ ), maka diperoleh persamaan gradien

$a=\frac{T^{2}}{m}=\frac{4 \pi^{2}}{k}$

sehingga untuk

menentukan

konstanta pegas

dihitung

menggunakan persamaan

$k=\frac{4 \pi^{2}}{a}$

Metode regresi linear ini juga digunakan untuk menentukan koefisien deterministik, standar deviasi, dan ketidakpastian dari data yang diperoleh pada saat eksperimen.

Metode kedua yang digunakan dalam penelitian ini adalah metode RK4. Metode tersebut merupakan metode yang dipakai untuk menyelesaikan persamaan diferensial dengan pendekatan deret Taylor dan persamaannya dituliskan sebagai berikut

$k_{1}=f\left(x_{n}, y_{n}\right)$

$$
\begin{aligned}
& k_{2}=f\left(x_{n}+\frac{h}{2}, y_{n}+\frac{h k_{1}}{2}\right)(9) \\
& k_{3}=f\left(x_{n}+\frac{h}{2}, y_{n}+\frac{h k_{2}}{2}\right)(10) \\
& k_{4}=f\left(x_{n}+h, y_{n}+h k_{3}\right)(11)
\end{aligned}
$$$$
y_{n+1}=y_{n}+h\left(\frac{k_{1}}{6}+\frac{k_{2}}{3}+\frac{k_{3}}{3}+\frac{k_{4}}{6}\right)(12)
$$

Metode ketiga yang digunakan dalam penelitian ini adalah ode45. Pemanggilan fungsi ode45 pada Matlab adalah sebagai berikut :

$[\mathrm{t}, \mathrm{y}]=$ ode45('fname', tspan, $\mathrm{y} 0$ );

Keterangan :

fname :nama fungsi dari Mfile yang digunakan.

tspan :dua elemen vektor yang mendefinisikan rentang dari waktu awal dan waktu akhir. :vektor dari kondisi awal untuk variabel y. 
Ketiga metode tersebut kemudian dikemas dalam bentuk GUI sehingga lebih mudah digunakan untuk analisis data eksperimen maupun konsep osilator harmonik pada pegas secara umum.

\section{HASIL DAN PEMBAHASAN}

GUI pada penelitian ini terdiri dari tiga buah jendela yaitu jendela utama, jendela regresi linear untuk pegas, serta jendela analisis pegas dengan RK4 dan ode45. GUI dibuat menggunakan bahasa pemrograman Matlab. Pada jendela utama GUI terdapat menu yang digunakan untuk memilih jendela yang akan dibuka. Pengguna dapat langsung memilih jendela mana yang akan digunakan dalam perhitungan dan analisis. Tampilan jendela utama GUI dapat dilihat pada gambar 1 .

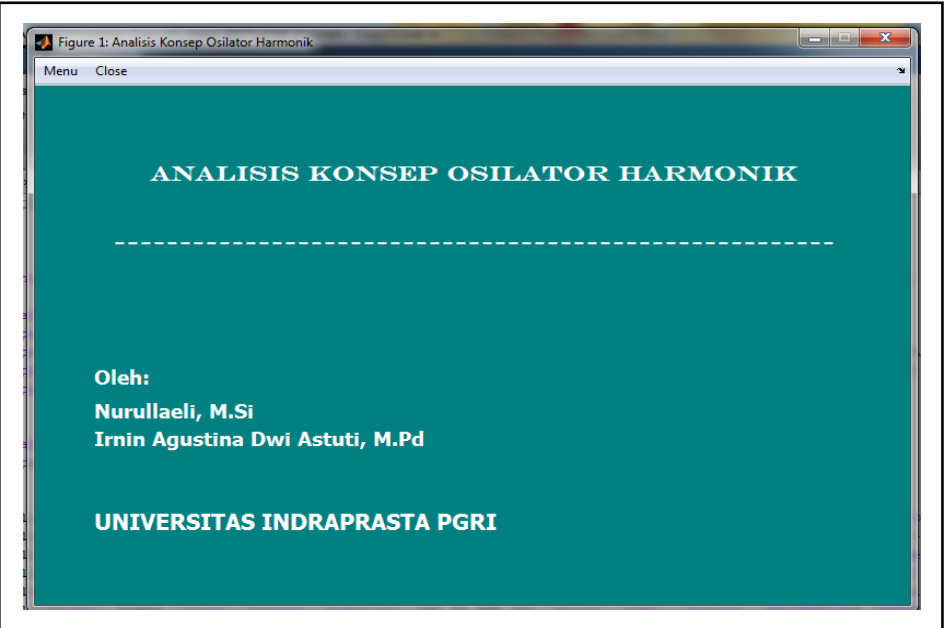

Gambar 1. Jendela Utama GUI

Jendela regresi linear untuk pegas digunakan untuk menganalisis data eksperimen yang telah dilakukan. Pada jendela ini terdapat perhitungan konstanta pegas, koefisien deterministik, standar deviasi, dan ketidakpastian. GUI regresi linear ini diharapkan dapat mempermudah dan mempercepat analisis data eksperimen yang biasanya membutuhkan waktu yang lama dan ketelitian yang tinggi. Hasil analisis data eksperimen pegas dengan GUI dapat dilihat pada gambar 2 .

Grafik hasil regresi linear dalam penelitian ini didapatkan nilai $a=23.4472, \quad b=1.6629, r^{2}=97.78 \%$, konstanta pegas $1.6837 \mathrm{~kg} / \mathrm{s}^{2}$, standar deviasi 0.16397, dan ketidakpastian 0.070367 . 
Nurullaeli., Agustina. -Media Analisis Osilator Harmonik...

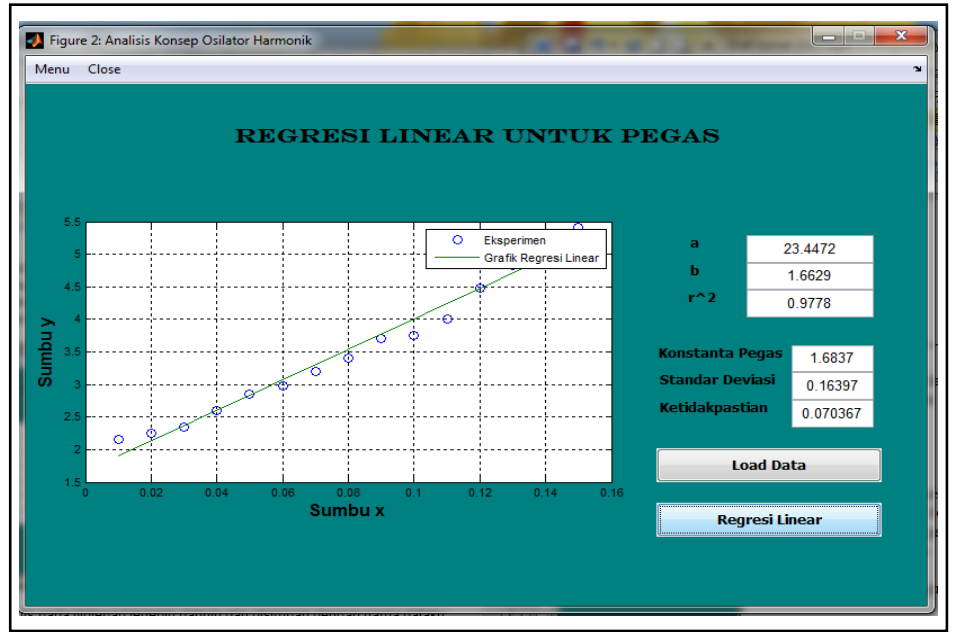

Gambar 2. Jendela Regresi Linear untuk Pegas

Tabel 1. Data Eksperimen Pegas

\begin{tabular}{cccc}
\hline $\mathbf{N o}$ & $\mathbf{m}(\mathbf{k g})$ & $\mathbf{T}(\mathbf{s})$ & $\mathbf{T}^{2}\left(\mathbf{s}^{2}\right)$ \\
\hline 1 & 0.01 & 1.467 & 2.152089 \\
2 & 0.02 & 1.498 & 2.244004 \\
3 & 0.03 & 1.534 & 2.353156 \\
4 & 0.04 & 1.61 & 2.592100 \\
5 & 0.05 & 1.687 & 2.845969 \\
6 & 0.06 & 1.724 & 2.972176 \\
7 & 0.07 & 1.789 & 3.200521 \\
8 & 0.08 & 1.846 & 3.407716 \\
9 & 0.09 & 1.923 & 3.697929 \\
10 & 0.1 & 1.937 & 3.751969 \\
11 & 0.11 & 2.001 & 4.004001 \\
12 & 0.12 & 2.116 & 4.477456 \\
13 & 0.13 & 2.196 & 4.822416 \\
14 & 0.14 & 2.269 & 5.148361 \\
15 & 0.15 & 2.326 & 5.410276 \\
\hline
\end{tabular}

Ketepatan GUI dalam menghitung konstanta pegas juga diuji dengan data peneliti lain. Berdasarkan penelitian Alkautsar dan Suprijadi (2012), penentuan konstanta pegas melalui metode dinamik dengan cara pengolahan citra menghasilkan konstanta pegas sebesar $8224.67 \mathrm{~g} / \mathrm{s}^{2}$ atau $8.22 \mathrm{~kg} / \mathrm{s}^{2}, 4.05 \%$ lebih besar dari pengamatan mekanik. Penggunaan GUI menjadikan analisis data yang diperoleh dari pengolahan 
Nurullaeli., Agustina. -Media Analisis Osilator Harmonik...

citra ataupun mekanik dapat (2012). Sedikit perbedaan dilakukan dengan cepat. Pada cara perhitungan diakibatkan karena pengolahan citra didapatkan konstanta perhitungan dengan GUI mempunyai pegas sebesar $8.4706 \mathrm{~kg} / \mathrm{s}^{2}$ dan pada ketelitian yang lebih tinggi cara mekanik didapatkan konstanta dibandingkan perhitungan manual. pegas $7.8554 \mathrm{~kg} / \mathrm{s}^{2}$.

Tampilan jendela GUI untuk

Hasil perhitungan yang didapat perhitungan tersebut dapat dilihat dari GUI hampir sama dengan pada gambar 3 dan 4.

perhitungan Alkautsar dan Suprijadi

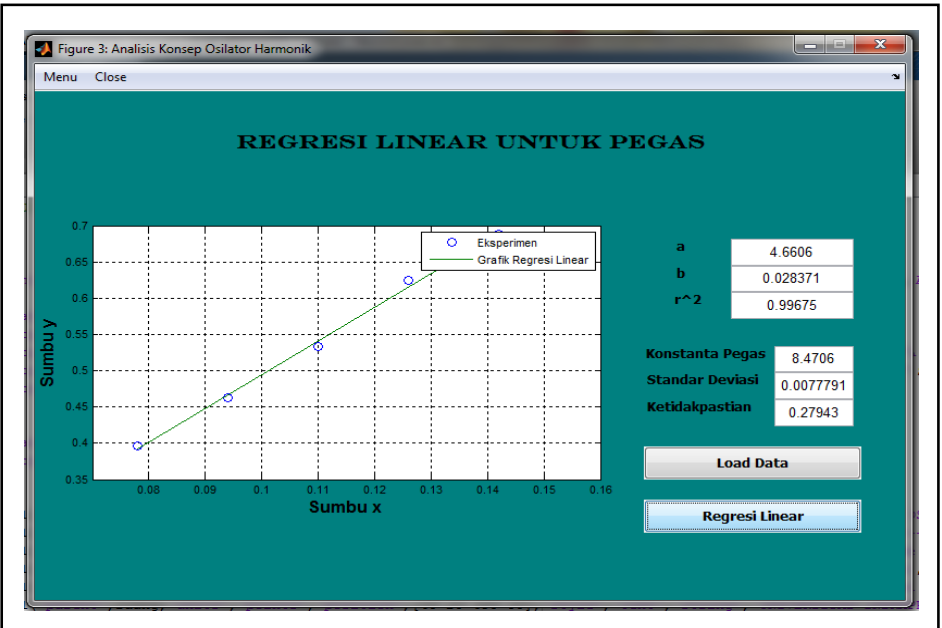

Gambar 3. JendelaGUI Perhitungan Konstanta Pegas dari Cara Pengolahan Citra

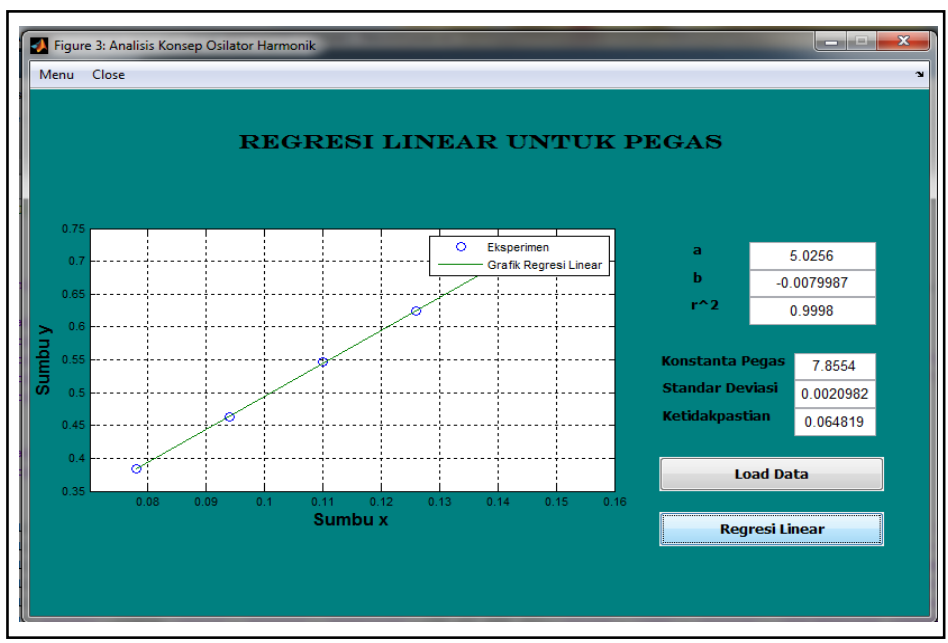

Gambar 4. Jendela GUI Perhitungan Konstanta Pegas dari Cara Mekanik 
Menu analisis pegas menggunakan metode RK4 dan ode45 digunakan untuk analisis konsep osilator harmonik pada pegas, salah satunya untuk mengetahui pengaruh nilai masukan pada bentuk grafik osilator harmonik pada pegas. Nilai masukan tersebut terdiri dari konstanta pegas, massa benda, konstanta redaman, selang waktu, inisial kondisi jarak mula-mula, inisial kondisi kecepatan mula-mula, dan jumlah langkah pengulangan. GUI ini dapat digunakan untuk analisis pegas teredam.

Persamaan osilator harmonik pada pegas yang mempunyai konstanta pegas $\mathrm{k}$ diberi beban $\mathrm{m}$ dan mengalami gesekan dengan konstanta redaman $b$ dapat ditulis sebagai berikut

$m+k x+b \frac{d x}{d t^{2}}=0$

Pada analisis menggunakan metode RK4 dan ode45, persamaan di atas diubah menjadi dua persamaan diferensial biasa sebagai berikut

$\frac{d x}{d t}=v$

$\frac{d x}{d t}=v$

Dari kedua persamaan tersebut akan didapatkan hasil analisis osilator harmonik pada pegas. Simulasi untuk analisis osilator harmonik pada pegas dapat dilihat pada gambar 5 dan 6.

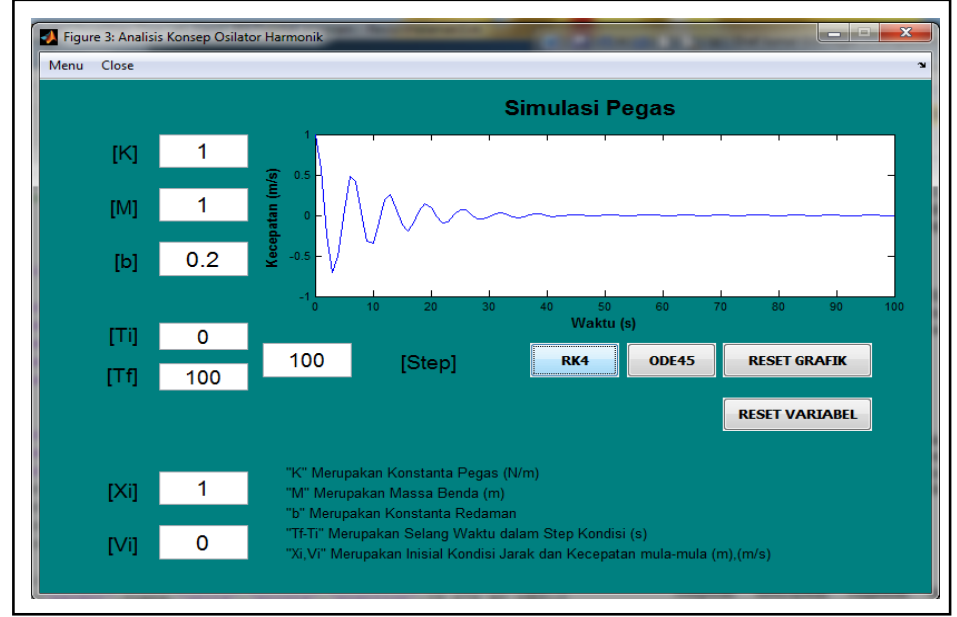

Gambar 5. Jendela Analisis Pegas Menggunakan Metode RK4 
Nurullaeli., Agustina. -Media Analisis Osilator Harmonik...

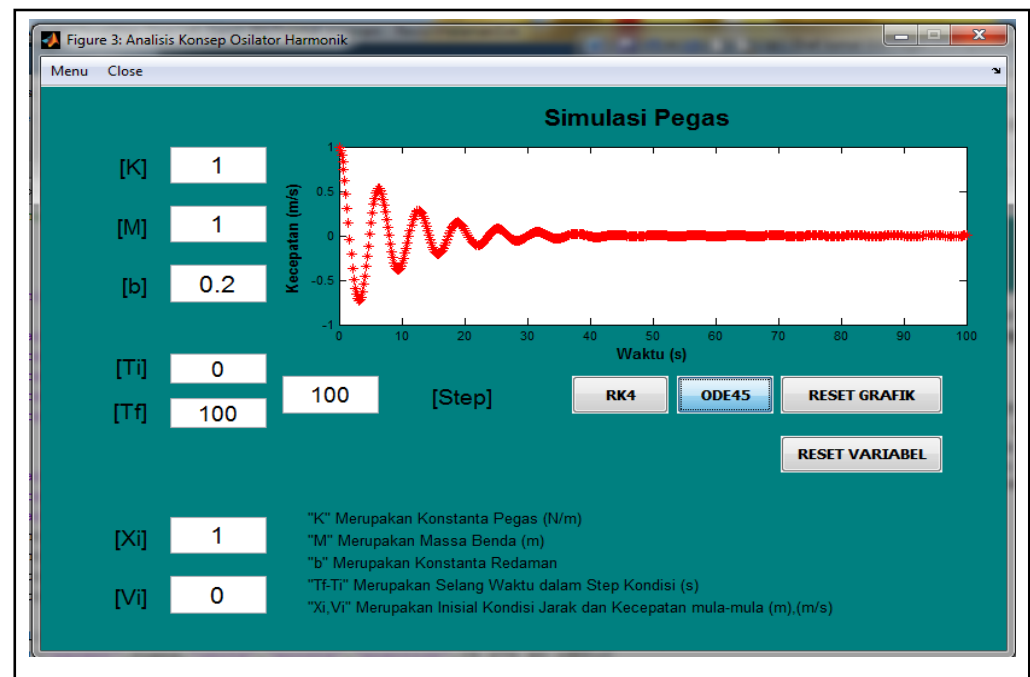

Gambar 6. Jendela Analisis Pegas Menggunakan Metode ode45

\section{Ucapan Terima Kasih}

Apresiasi dan terima kasih kepada Lembaga Penelitian dan Pengabdian Masyarakat Universitas Indraprasta PGRI yang telah membiayai penelitian ini, serta pengelola Jurnal Pendidikan Fisika Universitas Muhammadiyah Metro yang telah bersedia mempublikasikan hasil penelitian ini.

\section{KESIMPULAN DAN SARAN}

Graphic User Interface (GUI) dapat digunakan sebagai media analisis data eksperimen dan media analisis konsep osilator harmonik pada pegas. Pengunaan GUI ini akan membuat analisis lebih efektif dan efisien. Perbedaan perhitungan GUI dengan perhitungan manual diakibatkan karena perhitungan dengan GUI mempunyai ketelitian yang lebih tinggi. Dalam analisis konsep osilator harmonik pada pegas, metode numerik ode45 untuk rentang waktu yang lebar lebih mendekati nilai sebenarnya dibanding metode RK4.Perlu dilakukan pengembangan teori baru, dan/atau penelitian lanjutan sehingga dapat menyajikan analisis yang lebih lengkap.

\section{DAFTAR PUSTAKA}

Apriandi, D., \& Setyansah, R. K. (2017). Penerapan Media Simulasi Matlab Berbasis Interactive Conceptual untuk Meningkatan Pemahaman Konsep Mahasiswa. AKSIOMA: Jurnal Program Studi 
Nurullaeli., Agustina. -Media Analisis Osilator Harmonik...

Pendidikan Matematika, 6(2), 189-197.

Alkautsar, A., \& Suprijadi, S. (2012). Studi Pengukuran Konstanta Pegas dengan Pengolahan Citra. Jurnal Otomasi, Kontrol \& Instrumentasi, 4(2), 65-75.

Aththibby, A., Lubis, S., \& Ardiyanti, Y. (2019, July). Tpack as Innovation of Learning Science Laboratory of Indonesia. In 6th International Conference on Educational Research and Innovation (ICERI 2018). Atlantis Press.

Chapra, S, C. (2012). Applied numerical methods with MATLAB® for engineers and scientists third edition. New York: McGraw-Hill.

Costa, J, D., Trihandaru., \& Santi, M, R. S. (2014). Analisis Numerik untuk Gerak Osilasi Bergandeng pada Air Track dengan Metode Runge-Kutta. Prosiding Pertemuan Ilmiah XXVIII HFI Jateng \& DIY, Yogyakarta, 26 April 2014, 1417.

Fardinah, F. (2017). Solusi Persamaan Diferensial Biasa dengan Metode Runge-Kutta Orde Lima. Jurnal MSA (Matematika Dan Statistika Serta Aplikasinya), 5(1), 30-36.

Hutagalung, S. N. (2018). Pembelajaran Fisika Dasar dan Elektronika

Dasar

Menggunakan Aplikasi Matlab Metode Simulink. Journal of Science and Social Research, 1(1), 30-35.

Leader, Jeffery J. (2004). Numerical
Analysis and Scientific

Computation. Addison Wesley.

López Cruz, C. S. \& Gutierrez Cortes, F. I. (2012). Mobility in Learning: Interdisciplinary Experiences. In Proceedings of World Conference on ELearning in Corporate, Government, Healthcare, and Higher Education 2012 (pp. 1845-1849). Chesapeake, VA: AACE.

Nurullaeli, N., \& Astuti, I. A. D. (2018). Pembuatan Graphic User Interface (GUI) untuk Analisis Ayunan Matematis Menggunakan Matlab. Titian Ilmu: Jurnal Ilmiah Multi Sciences, 10(2), 48-56.

Santosa, I. E. (2010). Pengukuran Konstanta Pegas Secara Sederhana Berbasis Komputer. Prosiding Pertemuan Ilmiah XXIV HFI Jateng \& DIY, Semarang 10 April 2010, 210214.

Sihombing, S.C., \& Dahlia, A. (2018). Penyelesaian Persamaan Diferensial Linier Orde Satu dan Dua disertai Nilai Awal dengan menggunakan Metode Runge Kutta Orde Lima Butcher dan Felhberg (RKF45). Jurnal Matematika Integratif, 14(1), 51-60. 